\title{
Journal of Food Science and Technology Nepal (JFSTN): At a Glance
}

\author{
NAWA RAJ DAHAL ${ }^{1 *}$ and GANESH DAWADI
}

Editorial Board, JFSTN, Volume 1, 2005 to Volume 5, 2009

Nepal Food Scientists and Technologists Association (NEFOSTA)

Department of Food Technology and Quality Control, Babarmahal, Kathmandu, Nepal

\begin{abstract}
Journal of Food Science and Technology Nepal (JFSTN) is one of the major publications of Nepal Food Scientists and Technologists (NEFOSTA). In the history of its 25 years from its formation in 1984, JFSTN had begun to publish from twenty years of age and at this moment; five issues of JFSTN (Volume 1, 2005 to Volume 5, 2009 as an annual basis) have been published. JFSTN includes five different types of papers i.e. Review articles, Research papers, Research notes, View points and Short Communications. Altogether one hundred and one articles of different types (Review articles 28, Research papers 48, Research notes 23, viewpoint 1 and short communication 1) are published in these five issues of JFSTN (12, 27, 20, 17 and 25 at issue 1 to 5 respectively). This article wishes to explore the information about the status and significance of JFSTN for the development of Food Technology Profession in Nepal.
\end{abstract}

Keywords: NEFOSTA, JFSTN, Review article, Research paper, Nepal

\section{Introduction}

Journal of Food Science and Technology Nepal (JFSTN) is one of outstanding outcome and its publication is one of the major activities of NEFOSTA. JFSTN which is devoted to Research and Development contributions in all branches of Food Science and Technology is an annual publication of NEFOSTA. JFSTN has begun to publish from September, 2005 i.e. the first issue is JFSTN, Volume 1, 2005. In this five year (i.e. 2005 to 2009), fifth issue of JFSTN i.e. JFSTN 5, 2009 has been already published in September 2009 and at this moment, the process of editing of JFSTN 6, 2010 is in the progress. The objective of this paper is to explore the significance and status of the JFSTN in the area of Food Science and Technology at national and international community.

\section{Signification of JFSTN}

JFSTN publishes five different types of papers viz (a) Review articles on specific topics of higher utility and current trends not exceeding 12,000 words (b) Research papers not exceeding 8,000 words (c) Research notes not exceeding 4,000 words (d) Viewpoints not exceeding 8,000 words and (e) Short Communications of up to 3000 words. From the period of its existence, JFSTN begun to earn its reputation and respect from national and international level. JFSTN is helping many professionals of Food Science and Technology to get their Master's and Ph.D. Degree since publication is must to have Ph.D. Degree and also must to have Master Degree in some

\footnotetext{
*Corresponding author, E-mail: nawarajd@yahoo.com ${ }^{1}$ Poster presented at Silver Jubilee Program organized by NEFOSTA on Jan 23, 2010 in Kathmandu
}

of the countries like China. In addition, publication of paper in JFSTN is also helping professionals to get scholarship abroad to have their academic degrees. The pressure of receiving manuscripts from international as well as national community is increasing to JFSTN at this moment. There is also an international practice to evaluate the performance of professionals by the number of his/her publication (and the impact factor of the journal where the paper is published) rather than academic degrees only.

\section{Recognition of JFSTN by ISSN 1816-0727}

In order to recognize the identity of JFSTN at the international level, the process of registration at ISSN (International Standard Serial Number) office situated in France was preceded and JFSTN had been able to register there with ISSN 1816-0727 at July 20, 2005 completing the process of evaluation of journal, First issue of JFSTN, 1, 2005 was sent for the evaluation.

\section{Registration of JFSTN in NEPJOL}

NEPJOL, Nepal Journal Network, is the network established by Trivuwan University (TU), Kirtipur, Kathmandu so as to explore all of the journals published in Nepal in the website www.nepjol.info. JFSTN had been able to register in NEPJOL at June 8, 2009 and from that date professionals from any corner of the world can access the content of the JFSTN. An agreement was made by TU and NEFOSTA for the inclusion of JFSTN within the NEPJOL.

\section{Status of paper published in JFSTN}

On analyzing the status of papers published in JFSTN, it is clear that altogether one hundred and one articles of five 
different types (Review articles 28, Research papers 48, Research notes 23, viewpoint 1 and short communication 1) are published in these five issues of JFSTN i.e 12 articles in JFSTN, 1, 2005; 27 articles in JFSTN, 2, 2006; 20 articles in JFSTN, 3, 2007; 17 articles in JFSTN, 4, 2008 and 25 articles in JFSTN, 5, 200; the details is given in Table 1.

Similarly, on analyzing country wise contribution of papers, it is clear that about half (50 out of 101) of the papers are contributed by the professionals reflecting the work done outside the country, those professionals are either international professionals or Nepalese professionals worked outside during either their study period or working period. Rest of the papers 51 out of 101 are contributed by the professionals from home, the details is presented in Table 2. The detailed status of the papers published in JFSTN, 1, 2005 to JFSTN, 5, 2009 are presented in Table 3 to 7.

\section{Editing process of manuscript and publication of paper in JFSTN}

Editorial board of NEFOSTA is responsible for editing and publication of JFSTN. Guideline for authors is developed and is available in every issue of published JFSTN and also available in NEFOSTA website: nefosta.org. Authors are requested to follow the guideline critically before preparing and sending the manuscript. Manuscripts received to editorial board are firstly screened based on the format and requirements given in the guideline and then forwarded to the respective expert called reviewer to review critically (Name, address and Email of the authors are not disclosed to the reviewer). The list of the reviewers of JFSTN is given in Table 8.

Comments received by the reviewer are generally of five types (a) Manuscript accepted without any correction. (b) Manuscript acceptable with minor correction. (c) Manuscript acceptable with major corrections. (d) Manuscript not relevant to JFSTN and advised to send to the relevant journal and (e) Manuscript rejected. The comments received by the reviewer are then forwarded to the respective corresponding author of the respective manuscript for necessary correction as per the reviewer. In addition, editorial board reserves the privilege of editing the manuscript and adding or deleting relevant parts as well as rejecting the manuscript (if reviewers comments are not addressed properly and within scheduled time period) to make it suitable for publication in the journal. Further editorial board assumes no responsibility for the statements and options expressed by the contributors. Authors are also recommended to submit their original manuscript otherwise it is his/her responsibility for ethical issues and for necessary punishments if already published papers are included in the manuscript.

\section{Submission of manuscript to JFSTN}

All of the professionals related to Food Science and Technology are requested to submit their original manuscript (both in the form of hard and soft copy) of review articles, research papers, viewpoints and short communications to the address of editorial board of NEFOSTA. Any further clarification or confusion regarding to the preparation of manuscript and publication can also be addressed to editorial board of JFSNT.

\section{Mailing address}

NEFOSTA Editorial Board, C/O Department of Food Technology and Quality Control, Babarmahal, Kathmandu, Nepal.

Editor-in-Chief and Executive Editor of recent editorial board are Ganesh Dawadi (E-mail: ganeshdawadi@gmail.com) and Krishna Prasad Rai (Email: krishnamalarai@yahoo.com) respectively.

Since the regular schedule for publication of JFSTN is September in every year. Therefore, authors are requested to send manuscript not later than 30 March. Contributors are requested to follow Guidelines for Authors Critically while preparing their manuscripts. Guideline for Author is also available in NEFOSTA website: nefosta.org.

\section{Contact address for subscription of JFSTN and for other} publications

For subscription of JFSTN and other particulars, contact address is as follows.

The General Secretary, Nepal Food Scientists and Technologists Association (NEFOSTA) C/O Department of Food Technology and Quality Control, Kathmandu, Nepal. Phone: 00977-1-4262741, 00977-1-4262369; Fax: 00977-1-426233, Email: nefostaexcom@yahoo.com

\section{Concluding remarks}

In the history of 25 years of NEFOSTA, publication work for JFSTN started at its twenty years of age and at the end of twenty five years, five issues of JFSTN have been published. At this moment, altogether one hundred and one articles (Review articles 28, Research papers 48, Research notes 23, viewpoint 1 and short communication 1) are published in these five issues of JFSTN. In the short period of its existence, it has earned excellent reputation and scientific forum as well as appreciation from the respective professionals and related institutions. Of course, publication of journal is a challenging task but it has opened the tremendous opportunities to professionals and institutions to exchange and disseminate the developed knowledge on food Science and Technology both at the national and international level. Continuity of the publication of JFSTN is great success of NEFOSTA to achieve its objective. Editorial board of JFSTN wishes to continue publishing as well as improving the quality of this journal regularly and professionals in this area are kindly requested to for valuable feedbacks of suggestions and support for the continuity of JFSTN. 
Table 1. Summary of the papers Published in JFSTN (Vol-1, 2005 to Vol-5, 2009)

\begin{tabular}{ccccccc}
\hline Issue & Review Article & $\begin{array}{c}\text { Research } \\
\text { Paper }\end{array}$ & $\begin{array}{c}\text { Research } \\
\text { Note }\end{array}$ & View Point & $\begin{array}{c}\text { Short } \\
\text { Communication }\end{array}$ & $\begin{array}{c}\text { Total } \\
\text { JFSTN, 1, 2005 }\end{array}$ \\
JFSTN, 2, 2006 & 6 & 2 & 4 & - & - & $\mathbf{1 2}$ \\
JFSTN, 3, 2007 & 7 & 16 & 3 & - & - & $\mathbf{2 7}$ \\
JFSTN, 4, 2008 & 3 & 12 & 1 & - & - & $\mathbf{2 0}$ \\
JFSTN, 5, 2009 & 4 & 7 & 7 & - & 1 & $\mathbf{1 7}$ \\
Total & $\mathbf{2 8}$ & 11 & 8 & 1 & $\mathbf{1}$ & $\mathbf{1 0 1}$ \\
\hline
\end{tabular}

(Source: NEFOSTA, 2005 to NEFOSTA, 2009)

Table 2. Country wise Contribution of papers (Published) in JFSTN (Vol-1 to Vol-5)

\begin{tabular}{|c|c|c|c|c|c|c|}
\hline Country & $\begin{array}{c}\text { JFSTN, } 1, \\
2005\end{array}$ & $\begin{array}{c}\text { JFSTN, } 2 \text {, } \\
2006\end{array}$ & $\begin{array}{c}\text { JFSTN, 3, } \\
2007\end{array}$ & $\begin{array}{c}\text { JFSTN, 4, } \\
2008\end{array}$ & $\begin{array}{c}\text { JFSTN, } 5 \text {, } \\
2009\end{array}$ & Total \\
\hline Australia & 1 & 1 & 1 & 1 & 1 & 5 \\
\hline Bangladesh & - & - & - & 1 & - & 1 \\
\hline Belgium & - & - & - & - & 1 & 1 \\
\hline China & 3 & 5 & 4 & 2 & 2 & 16 \\
\hline India & - & 5 & 2 & 1 & 7 & 15 \\
\hline Japan & - & 1 & 2 & 1 & - & 4 \\
\hline Nepal & 8 & 11 & 10 & 10 & 12 & 51 \\
\hline Nigeria & - & 4 & 1 & - & - & 5 \\
\hline Srilanka & - & - & - & 1 & 1 & 2 \\
\hline Thailand & - & - & - & - & 1 & 1 \\
\hline Total & 12 & 27 & 20 & 17 & 25 & 101 \\
\hline
\end{tabular}

(Source: NEFOSTA, 2005 to NEFOSTA, 2009)

Table 3. An overview of Papers Published in JFSTN, 1, 2005

\begin{tabular}{|c|c|c|c|}
\hline Type of Paper & Title of Paper & Authors Name & Country \\
\hline Review Article & $\begin{array}{l}\text { Folates: A Review on stability, Bioavailability, Fortification and } \\
\text { Analysis }\end{array}$ & $\begin{array}{l}\text { A.K. Shrestha and J. } \\
\text { Arcot }\end{array}$ & Australia \\
\hline Review Article & $\begin{array}{l}\text { An Overview on IPM Approaches for Maintaining Healthy } \\
\text { Honeybee Colonies and Quality of Honey }\end{array}$ & N.P. Bhandari & Nepal \\
\hline Review Article & $\begin{array}{l}\text { Calcium Carbide for Artificial Ripening of Fruits-Its application } \\
\text { and Hazards }\end{array}$ & $\begin{array}{l}\text { U. K. Bhattarai and } \\
\text { K.Shrestha }\end{array}$ & Nepal \\
\hline Review Article & Fermented Foods of Nepal- A Brief Review & $\begin{array}{l}\text { J. B. K.C. and T.B. } \\
\text { Thapa }\end{array}$ & Nepal \\
\hline Review Article & $\begin{array}{l}\text { Post harvest Management for Export Marketing of Oranges of } \\
\text { Nepal }\end{array}$ & P.M. Shakya & Nepal \\
\hline Review Article & Safety Aspects of Biogenic Amines in Cheese & $\begin{array}{l}\text { B. Chitrakar and Z. } \\
\text { Guonong }\end{array}$ & China \\
\hline Research Paper & $\begin{array}{l}\text { Physicochemical and Biochemical Changes during Ripening of } \\
\text { Dry Fermented Chinese-style Sausages Inoculated with Lactic } \\
\text { Acid Bacteria }\end{array}$ & $\begin{array}{l}\text { K.P. Rai, A.K. Shrestha } \\
\text { and W. Xia }\end{array}$ & China \\
\hline Research Paper & $\begin{array}{l}\text { Influence of Pediococcus pentosans, Saccharomyces cerevisiae } \\
\text { and Aspergillus niger on Sensory, Biochemical and Nutritional } \\
\text { Characteristics of Masyaura- A Legume-based Traditional } \\
\text { Fermented food of Nepal }\end{array}$ & N.R. Dahal and L.Qi & China \\
\hline Research Note & $\begin{array}{l}\text { Preparation of Carrot Candy and Study on its Quality } \\
\text { Parameters }\end{array}$ & S. Katawal and S. Kafle & Nepal \\
\hline Research Note & Preservation of Strained Jand by Pasteurization & $\begin{array}{l}\text { G. Mongar and B. K. } \\
\text { Rai }\end{array}$ & Nepal \\
\hline Research Note & Preparation of Paneer from Sour Milk & $\begin{array}{l}\text { G.P. Kharel, P. P. } \\
\text { Acharya and R. Sapkota }\end{array}$ & Nepal \\
\hline Research Note & $\begin{array}{l}\text { Monitoring Good Manufacturing Practices of Dairy Industries } \\
\text { in Nepal }\end{array}$ & $\begin{array}{l}\text { J. P. Lama and T. B. } \\
\text { Karki }\end{array}$ & Nepal \\
\hline
\end{tabular}

(Source: NEFOSTA, 2005) 
Table 4. An overview of papers published in JFSTN, 2, 2006

\begin{tabular}{|c|c|c|c|}
\hline $\begin{array}{l}\text { Type of } \\
\text { Paper }\end{array}$ & Title of Paper & Authors Name & Country \\
\hline $\begin{array}{l}\text { Review } \\
\text { Article }\end{array}$ & $\begin{array}{l}\text { Some Indigenous Limbu Foods of Dhankutta } \\
\text { (district), Terhathum (district) and Dharan } \\
\text { (municipality, Sunsari district) }\end{array}$ & $\begin{array}{l}\text { B. K. Rai, D. K. Subba, } \\
\text { K.P. Limbu and K. Maden }\end{array}$ & Nepal \\
\hline $\begin{array}{l}\text { Review } \\
\text { Article }\end{array}$ & An Overview of Malnutrition in Nepal & $\begin{array}{l}\text { B.K. Sharma, P.C. Wasti } \\
\text { and U.K. Bhattarai }\end{array}$ & Nepal \\
\hline $\begin{array}{l}\text { Review } \\
\text { Article }\end{array}$ & Noodle Technology in Nepal- A Brief Review & H. B. Thapa and G. Dawadi & Nepal \\
\hline $\begin{array}{l}\text { Review } \\
\text { Article }\end{array}$ & Probiotics: Selection and Health Benefits & $\begin{array}{l}\text { D. Thapa, Y.Ying and Z. } \\
\text { Hao }\end{array}$ & China \\
\hline $\begin{array}{l}\text { Review } \\
\text { Article }\end{array}$ & $\begin{array}{l}\text { Chitosan: A functional Biopolymer for Foods and } \\
\text { Pharmaceuticals }\end{array}$ & K.P. Rai and X.W. Shui & China \\
\hline $\begin{array}{l}\text { Review } \\
\text { Article }\end{array}$ & Mycotoxins in Milk and Milk products: A Review & $\begin{array}{l}\text { R. P. Adhikary, C.M. } \\
\text { Bhandari, J. L. Lamsal and } \\
\text { A. Halwai }\end{array}$ & Nepal \\
\hline $\begin{array}{l}\text { Review } \\
\text { Article }\end{array}$ & Nisin -A Major Bacteriocin of Lactic Acid Bacteria & N. R. Dahal and T. Fengwei & China \\
\hline $\begin{array}{l}\text { Review } \\
\text { Article }\end{array}$ & $\begin{array}{l}\text { Risk Analysis- An Unavoidable Scientific Process } \\
\text { for Assuring Safety in Food Chain. }\end{array}$ & $\begin{array}{l}\text { A. Adhikari, J.P. Lama and } \\
\text { T.B. Karki }\end{array}$ & Nepal \\
\hline $\begin{array}{l}\text { Research } \\
\text { Paper }\end{array}$ & $\begin{array}{l}\text { Morbidity Profile and Prevalence of Anemia in } \\
\text { Indian Women from a Rural Coastal Community }\end{array}$ & $\begin{array}{l}\text { P.A. Machado and J. } \\
\text { Prakash }\end{array}$ & India \\
\hline $\begin{array}{l}\text { Research } \\
\text { Paper }\end{array}$ & $\begin{array}{l}\text { Effect of Lactic Acid on Spray Drying Behavior of } \\
\text { Acid-Whey and Study of their Glass Transition } \\
\text { Temperature }\end{array}$ & $\begin{array}{l}\text { A.K. Shrestha, T. Howes, } \\
\text { B.P. Adhikari and B.R. } \\
\text { Bhandari }\end{array}$ & Australia \\
\hline $\begin{array}{l}\text { Research } \\
\text { Paper }\end{array}$ & $\begin{array}{l}\text { Effect of Microbial Transglutaminase and Sodium } \\
\text { Caseinate on Mechanical Properties of Batter Gel as } \\
\text { dependent on cooking method }\end{array}$ & U. Marapana and B. Jiang & China \\
\hline $\begin{array}{l}\text { Research } \\
\text { Paper }\end{array}$ & $\begin{array}{l}\text { Assessment of Oxalate and Phytate levels and } \\
\text { Bioavailability of calcium and Zinc in Masyaura }\end{array}$ & N. R. Dahal and L. Qi & China \\
\hline $\begin{array}{l}\text { Research } \\
\text { Paper }\end{array}$ & $\begin{array}{l}\text { Detection Threshold and Flavour Potentiating Effect } \\
\text { of Monosodium Glutamate }\end{array}$ & $\begin{array}{l}\text { I. Maqbool H. and J. } \\
\text { Prakash }\end{array}$ & India \\
\hline $\begin{array}{l}\text { Research } \\
\text { Paper }\end{array}$ & $\begin{array}{l}\text { Effect of Processing and Frozen Storage on the } \\
\text { Retention of Ascorbic Acid and } \beta \text { - Carotene of } \\
\text { Selected Vegetables }\end{array}$ & $\begin{array}{l}\text { J.K. Brar, S.K. Mann and } \\
\text { K. Bains }\end{array}$ & India \\
\hline $\begin{array}{l}\text { Research } \\
\text { Paper }\end{array}$ & $\begin{array}{l}\text { Peroxidase activity, Chlorophylls and Antooxident } \\
\text { Profile of Two Leaf Vegetables (Solanium nigrum } \\
\text { L. and Amaranthus cruentus L.) }\end{array}$ & $\begin{array}{l}\text { O. C. Adeboyee, M.R. } \\
\text { Vijayalaxmi and V. Singh }\end{array}$ & India \\
\hline $\begin{array}{l}\text { Research } \\
\text { Paper }\end{array}$ & $\begin{array}{l}\text { Study on Moisture Sorption Behaviour of CTC } \\
\text { Black Tea }\end{array}$ & D. Khanal and D. B. Karki & Nepal \\
\hline $\begin{array}{l}\text { Research } \\
\text { Paper }\end{array}$ & $\begin{array}{l}\text { Effect of pH on Physico-chemical and Sensory } \\
\text { Characteristics of Mozzarella Cheese }\end{array}$ & $\begin{array}{l}\text { P. P. Acharya and J. P. } \\
\text { Mishra }\end{array}$ & Nepal \\
\hline $\begin{array}{l}\text { Research } \\
\text { Paper }\end{array}$ & $\begin{array}{l}\text { Preparation of Lapsi (Choerospondias axillaries } \\
\text { roxb.) Pulp using IMF Technology and Study on } \\
\text { Storage Stability }\end{array}$ & $\begin{array}{l}\text { K. Shrestha, B.P. Shrestha } \\
\text { and U. K. Bhattarai }\end{array}$ & Nepal \\
\hline $\begin{array}{l}\text { Research } \\
\text { Paper }\end{array}$ & $\begin{array}{l}\text { Proximate, Mineral and Amino Acid Compositions } \\
\text { of Common Legumes Consumed in Nepal }\end{array}$ & $\begin{array}{l}\text { M. R. Bhandari and G. } \\
\text { Dawadi }\end{array}$ & Japan \\
\hline $\begin{array}{l}\text { Research } \\
\text { Paper }\end{array}$ & $\begin{array}{l}\text { Design and Construction of Solar Incubator in } \\
\text { Nigeria }\end{array}$ & $\begin{array}{l}\text { B. A. Adewumi, A. A. A. } \\
\text { Odunmbaku and K. Bayode }\end{array}$ & Nigeria \\
\hline $\begin{array}{l}\text { Research } \\
\text { Paper }\end{array}$ & Evaluation of Antioxident activity of Ocimum sp & $\begin{array}{l}\text { B. O. T. Ifesan, O.S. } \\
\text { Ijarotimi and O. F. } \\
\text { Osundahunsi }\end{array}$ & Nigeria \\
\hline $\begin{array}{l}\text { Research } \\
\text { Paper }\end{array}$ & $\begin{array}{l}\text { A Study of Some Physical and Mechanical } \\
\text { properties of Coconut sp }\end{array}$ & S. I. Manuwa & Nigeria \\
\hline Research Note & $\begin{array}{l}\text { The Moisture and Temperature Profiles of Cocoa } \\
\text { Stored in Jute and Hessian bags }\end{array}$ & F. R. Falayi & Nigeria \\
\hline
\end{tabular}




\begin{tabular}{|c|c|c|c|}
\hline $\begin{array}{l}\text { Research } \\
\text { Paper }\end{array}$ & $\begin{array}{l}\text { Evaluation of Biscuits Enriched with Tempe and } \\
\text { Soyflour on Pre-School Children in Rural area }\end{array}$ & $\begin{array}{l}\text { Vijayalaxmi D., Jamuna K. } \\
\text { V. and Shivshankar }\end{array}$ & India \\
\hline Research Note & $\begin{array}{l}\text { Storage of Fresh White Button Mushroom in Cool } \\
\text { Chamber }\end{array}$ & $\begin{array}{l}\text { M.J. Thapa, M. B. Shrestha } \\
\text { and R. C. Bhandari }\end{array}$ & Nepal \\
\hline $\begin{array}{l}\text { Research } \\
\text { Paper }\end{array}$ & $\begin{array}{l}\text { Delta-endotoxin Immuno Cross-reactivity of } \\
\text { Bacillus thuringiensis Isolates Collected from } \\
\text { Khumbu Base Camp of Mount Everest Region }\end{array}$ & $\begin{array}{l}\text { U. T. Shrestha, G. S. } \\
\text { Sahukhal, S Pokheral. K. B. } \\
\text { Tiwari, A. Singh and V. P. } \\
\text { Agrawal. }\end{array}$ & Nepal \\
\hline Research Note & $\begin{array}{l}\text { Prevalence of Vitamin A Deficiency and Iodine } \\
\text { Deficiency Disorder in the Mid- Western } \\
\text { Development Region of Nepal }\end{array}$ & U. Ray & Nepal \\
\hline
\end{tabular}

(Source: NEFOSTA, 2006)

Table 5. An overview of papers published in JFSTN, 3, 2007

\begin{tabular}{|c|c|c|c|}
\hline $\begin{array}{l}\text { Type of } \\
\text { Paper }\end{array}$ & Title of Paper & Authors Name & Country \\
\hline Review & Traditional Foods and Beverages of Newari & H. Shrestha and E.R. Rao & Nepal \\
\hline Article & Community- A Brief Review & & \\
\hline $\begin{array}{l}\text { Review } \\
\text { Article }\end{array}$ & $\begin{array}{l}\text { Common Tea Pests and Use of Pesticides in Tea in } \\
\text { Nepal }\end{array}$ & $\begin{array}{l}\text { P. Koirala, D. B. Khadka, } \\
\text { S. Dhital and J. P Lama }\end{array}$ & Nepal \\
\hline Review & Hazard Analysis and Critical Control Point & S. Dhital, G. Agrawal and & Nepal \\
\hline Article & (HACCP) in Pig Slaughtering in Nepal & B.N. Vaidya & \\
\hline $\begin{array}{l}\text { Review } \\
\text { Article }\end{array}$ & $\begin{array}{l}\text { Safety aspects of Biogenic Amines (Bas) in Muscle } \\
\text { Foods }\end{array}$ & K. P. Rai and W. Xia & China \\
\hline $\begin{array}{l}\text { Review } \\
\text { Article }\end{array}$ & $\begin{array}{l}\text { Latte (Amaranth): A Nutritious Alternative Grain as } \\
\text { a Functional Food }\end{array}$ & $\begin{array}{l}\text { M.R. Bhandari. U.K. } \\
\text { bhattrai and J. Kawabata }\end{array}$ & Japan \\
\hline $\begin{array}{l}\text { Review } \\
\text { Article }\end{array}$ & $\begin{array}{l}\text { Functional Properties of Food Application of } \\
\text { Chiraito- A Medicinal Plant of Nepal }\end{array}$ & $\begin{array}{l}\text { A. Upadhaya, G. Dawadi } \\
\text { and J. P. Lama }\end{array}$ & Nepal \\
\hline $\begin{array}{l}\text { Review } \\
\text { Article }\end{array}$ & Sources and Causes of Bacterial Load in Raw Milk & D. Khanal & Nepal \\
\hline $\begin{array}{l}\text { Research } \\
\text { Paper }\end{array}$ & $\begin{array}{l}\text { Effects of Extrusion on Resistant Starch Content and } \\
\text { Structure of Low and High Amylose Starches }\end{array}$ & $\begin{array}{l}\text { A. K. Shrestha and R. } \\
\text { Khadka }\end{array}$ & Australia \\
\hline $\begin{array}{l}\text { Research } \\
\text { Paper }\end{array}$ & $\begin{array}{l}\text { Thermally Induced Gelatin and Functional } \\
\text { Properties of Porcine Leg Myofibrillar }\end{array}$ & U. Marapana and B. Jiang & China \\
\hline $\begin{array}{l}\text { Research } \\
\text { Paper }\end{array}$ & $\begin{array}{l}\text { Insoluble and Soluble Dietary Fiber Content in } \\
\text { Vegetables Cooked by Different Methods }\end{array}$ & A. Kala and J. Prakash & India \\
\hline $\begin{array}{l}\text { Research } \\
\text { Paper }\end{array}$ & $\begin{array}{l}\text { Effects of Some Flavour Enhancers on Plasma and } \\
\text { Tissue Proteins, Lipids and MonoamineOxidase } \\
\text { Activity in Rats }\end{array}$ & $\begin{array}{l}\text { O. A. T. Ebuehi, B. O. } \\
\text { Kushanu, A. O. Dawodu } \\
\text { and I. O. Edufunke }\end{array}$ & Nigeria \\
\hline $\begin{array}{l}\text { Research } \\
\text { Paper }\end{array}$ & $\begin{array}{l}\text { Effects of Processing Methods on Removal of Toxic } \\
\text { and Antinutritional Constituents of Jatropha Meal: } \\
\text { A Potential Protein Source }\end{array}$ & $\begin{array}{l}\text { R.K. Devappa and B. } \\
\text { Swamilingappa }\end{array}$ & India \\
\hline $\begin{array}{l}\text { Research } \\
\text { Paper }\end{array}$ & $\begin{array}{l}\text { Growth and Survival of Lactic Acid Bacteria on } \\
\text { Acid and Bile Salt Concentrations }\end{array}$ & D. Thapa and Z. Hao & China \\
\hline $\begin{array}{l}\text { Research } \\
\text { Paper }\end{array}$ & $\begin{array}{l}\text { Effects of Nucleotides Supplementation on the } \\
\text { Growth of Bifidobacteria and Pathogenic Bacteria }\end{array}$ & $\begin{array}{l}\text { S. Kafley, M. M. Rahaman } \\
\text { and W.S. Kim }\end{array}$ & Japan \\
\hline $\begin{array}{l}\text { Research } \\
\text { Paper }\end{array}$ & $\begin{array}{l}\text { Organic Acids and Volatile Components in } \\
\text { Masyaura }\end{array}$ & N. R. Dahal and L. Qi & China \\
\hline $\begin{array}{l}\text { Research } \\
\text { Paper }\end{array}$ & $\begin{array}{l}\text { Quality Assessment of Packaged Drinking Water } \\
\text { Commercially Available in Kathmandu Valley }\end{array}$ & $\begin{array}{l}\text { D. N. Gautam, S. Joshi and } \\
\text { S. Upadhyay }\end{array}$ & Nepal \\
\hline $\begin{array}{l}\text { Research } \\
\text { Paper }\end{array}$ & $\begin{array}{l}\text { Coliform Load in Different Processing Steps and } \\
\text { Sources of Post-contamination in Diary Industries } \\
\text { Situated in Kathmandu Valley }\end{array}$ & $\begin{array}{l}\text { R. P. Adhikari and K. G. } \\
\text { Shrestha }\end{array}$ & Nepal \\
\hline Research Note & $\begin{array}{l}\text { Bacteriological Risk Analysis of Rural Water } \\
\text { Supply Schemes in Western Development Region of } \\
\text { Nepal }\end{array}$ & $\begin{array}{l}\text { S. Shakya, M.N. Shrestha } \\
\text { and S. K. Shakya }\end{array}$ & Nepal \\
\hline
\end{tabular}


Dahal \& Dawadi : J. Food Sci. \& Technol. Nepal, 6 (122-129), 2010

\begin{tabular}{cll}
\hline $\begin{array}{c}\text { Research } \\
\text { Paper }\end{array}$ & $\begin{array}{l}\text { Assessment of Microbiological Quality in Milk } \\
\text { Chain of Dairy Development Corporation, Balaju }\end{array}$ & $\begin{array}{l}\text { D. Bhatta, a. Halwai, M. r. } \\
\text { Bhandari, G, Dawadi and } \\
\text { T. B. Karki }\end{array}$ \\
$\begin{array}{c}\text { Research } \\
\text { Paper }\end{array}$ & $\begin{array}{l}\text { Study of Actinomycetes Isolates by Randomly } \\
\text { Amplified Polymorphic DNA- Polymerase Chain } \\
\text { Reaction ( Rapid -PCR) from Soil Samples of Lukla } \\
\text { of Everest Region }\end{array}$ & $\begin{array}{l}\text { H. M. Dhungana, G. S. } \\
\text { Sahukhal and V. P. } \\
\text { Agrawal }\end{array}$ \\
\hline
\end{tabular}

(Source: NEFOSTA, 2007)

Table 6. An overview of papers published in JFSTN, 4, 2008

\begin{tabular}{|c|c|c|c|}
\hline $\begin{array}{l}\text { Type of } \\
\text { Paper }\end{array}$ & Title of Paper & Authors Name & Country \\
\hline Review & Effect of Processing on Resistant Starch & A. K. Shrestha & Australia \\
\hline Article & Formation in Foods: A Review & & \\
\hline Review & Inhibition of Microbes in the Presence of & R. A. U. J. Marapana & Srilanka \\
\hline Review & Genetically Modified Organisium (GMO) and its & G. S. Sahukhal, B. L. & Nepal \\
\hline Article & Detection Methods & $\begin{array}{l}\text { Jayana, N. Dhungana, N. R. } \\
\text { Dahal, G. Dawadi, S. } \\
\text { Shrestha and V. P. Agrawal }\end{array}$ & \\
\hline Research & A Survey Study on Technology of Sel-roti- A & S.B. Katwal and D. Subba. & Nepal \\
\hline Paper & Traditional Food of Nepal & & \\
\hline Research Note & $\begin{array}{l}\text { Assessment of Certain Pesticide Residues in } \\
\text { Nepalese Tea }\end{array}$ & $\begin{array}{l}\text { P. Koirala, N.R. Dahal, J. P. } \\
\text { Lama and U. K. Bhattarai }\end{array}$ & Nepal \\
\hline $\begin{array}{l}\text { Research } \\
\text { Paper }\end{array}$ & $\begin{array}{l}\text { A Case Control Study on Risk Factor Associated } \\
\text { with Malnutrition in Dolpa District of Nepal. }\end{array}$ & S. Mehata & Nepal \\
\hline $\begin{array}{l}\text { Research } \\
\text { Paper }\end{array}$ & $\begin{array}{l}\text { Nutritional and Functional Properties of Kashk- } \\
\text { Fermented Sheep Milk Powder }\end{array}$ & M. Ogbaei and J. Prakash & India \\
\hline Research Note & Polyphenols and Antioxidents in Masyaura & N.R. Dahal and L. Qi & China \\
\hline $\begin{array}{l}\text { Research } \\
\text { Paper }\end{array}$ & $\begin{array}{l}\text { Study on Brewing quality of Naked Barley } \\
\text { (Hodeum Vulgare L.) }\end{array}$ & $\begin{array}{l}\text { D. R. Acharya and D. B. } \\
\text { Karki }\end{array}$ & Nepal \\
\hline Research Note & $\begin{array}{l}\text { Antibiotic Resistant Escherichia coli in Meat } \\
\text { Samples from Kathmandu Valley }\end{array}$ & $\begin{array}{l}\text { V. S. Chhetri. I. B. Pachhai, } \\
\text { P. Poudel, H. Bokkhim and } \\
\text { Y. Dabadi }\end{array}$ & Nepal \\
\hline Research Note & $\begin{array}{l}\text { Socio-Demographic and Nutritional Status of } \\
\text { Pregnant Mothers attending Maternity Centre of } \\
\text { Dhaka, Bangladesh }\end{array}$ & $\begin{array}{l}\text { B. K. Yadhav, A. Habib and } \\
\text { S. Ahmed }\end{array}$ & Bangladesh \\
\hline Research Note & $\begin{array}{l}\text { Assessment of Aflatoxin B1 Level in Chilli, Maize } \\
\text { and Groundnut Samples from Kathmandu Valley }\end{array}$ & $\begin{array}{l}\text { D. N. Gautam, R. Bhatta and } \\
\text { M. R. Bhandari }\end{array}$ & Nepal \\
\hline $\begin{array}{l}\text { Research } \\
\text { Paper }\end{array}$ & $\begin{array}{l}\text { Antidiabetic Activity of Laliguras (Rhododendron } \\
\text { arboretum Sm.) Flower of Nepal }\end{array}$ & $\begin{array}{l}\text { M. R. Bhandari and J. } \\
\text { Kawabata }\end{array}$ & Japan \\
\hline $\begin{array}{l}\text { Research } \\
\text { Paper }\end{array}$ & $\begin{array}{l}\text { Proteolytic Effect of Starter Cultures on Dry } \\
\text { Fermented Chinese- Style Sausage }\end{array}$ & $\begin{array}{l}\text { K. P. Rai, A. K. Shrestha } \\
\text { and W. Xia }\end{array}$ & China \\
\hline Research Note & $\begin{array}{l}\text { Storage Stability of Fermented Finger Millet } \\
\text { (Eleusine coracana) Packaged in PVC Container } \\
\text { under Ambient Conditions }\end{array}$ & D. B. Karki and G. P. Kharel & Nepal \\
\hline Research Note & $\begin{array}{l}\text { Production of Probiotic Soy-yoghurt by } \\
\text { Inoculating Lactic Acid Bacteria Isolated from } \\
\text { Yoghurt Samples from Kathmandu Valley }\end{array}$ & P. Poudel and T.B. Karki & Nepal \\
\hline $\begin{array}{l}\text { Research } \\
\text { Paper }\end{array}$ & $\begin{array}{l}\text { Screening of Cry- Type Genes among the Bacillus } \\
\text { thuringiensis Isolated from Soil Samples of } \\
\text { Phereche and Sagarmatha National Park of Mount } \\
\text { Everest Base camp Region by PCR }\end{array}$ & $\begin{array}{l}\text { G. S. Sahukhal, B. L. } \\
\text { Jayana, U. T. Shrestha, E. B. } \\
\text { Dov and V. P. Agrawal }\end{array}$ & Nepal \\
\hline
\end{tabular}

(Source: NEFOSTA, 2008) 
Table 7. An overview of papers published in JFSTN, 5, 2009

\begin{tabular}{|c|c|c|c|}
\hline Type of Paper & Title of Paper & Authors Name & Country \\
\hline Review Article & $\begin{array}{l}\text { Irradiation as an Effective Way of Microbial Control } \\
\text { in Food Preservation and Processing }\end{array}$ & $\begin{array}{l}\text { R. A. U. J. Marapana and S. } \\
\text { Wijetunga }\end{array}$ & Srilanka \\
\hline Review Article & $\begin{array}{l}\text { Ohmic Heating Applications in Food Processing: A } \\
\text { Review }\end{array}$ & $\begin{array}{l}\text { S. Patil, A. Singh and M. } \\
\text { Kulshrestha }\end{array}$ & India \\
\hline Review Article & Biobased Packaging Materials for the Food Industry & R. Shalini and A. Singh & India \\
\hline Review Article & $\begin{array}{l}\text { Pesticide Residue Monitoring and Quarantine System } \\
\text { of Some Selected Asian Countries with Reference to } \\
\text { Nepal }\end{array}$ & $\begin{array}{l}\text { P. Koirala and A. S. } \\
\text { Tamrakar }\end{array}$ & Nepal \\
\hline Research Paper & $\begin{array}{l}\text { Investigation on the Thermal Stability of Folic Acid } \\
\text { and 5-Methyltetrahydrofolic Acid in Model Liquid } \\
\text { Food Systems }\end{array}$ & $\begin{array}{l}\text { A. K. Shrestha, P. Torley } \\
\text { and P. E. Forissier }\end{array}$ & Australia \\
\hline Research Paper & $\begin{array}{l}\text { Low Salt Effects on Gelation and Textural Properties } \\
\text { of Pork Batter Gel Enhanced by Microbial } \\
\text { Transglutaminase and Cooking Method }\end{array}$ & U. Marapana and B. Jiang & China \\
\hline Research Paper & $\begin{array}{l}\text { Shelf Stability and Sensory Quality of a Fried Chick- } \\
\text { Pea Snack Incorporated with Soy Protein Concentrate }\end{array}$ & $\begin{array}{l}\text { R. Kumari R.K. and J. } \\
\text { Prakash }\end{array}$ & India \\
\hline Research Paper & $\begin{array}{l}\text { Genetic Variability of Three Xylanase-Inhibiting } \\
\text { Proteins Present In Wheat Grain }\end{array}$ & P. Oli and E. Cores & Belgium \\
\hline Research Paper & $\begin{array}{l}\text { Study on the Fractionation of Protein from Masyaura } \\
\text { and Their Nutritional Evaluation }\end{array}$ & N. R. Dahal and L. Qi & China \\
\hline Research Paper & $\begin{array}{l}\text { Antioxidant and Antibacterial Properties of Jatropha } \\
\text { (Jatropha curcas) Meal Extracts }\end{array}$ & $\begin{array}{l}\text { R. Devappa. K, S. K. Rajesh } \\
\text { and B. Swamylingappa }\end{array}$ & India \\
\hline Research Paper & $\begin{array}{l}\text { Effectiveness of Bojo (Acorus calmus) as Natural } \\
\text { Insecticide in Wheat Grain }\end{array}$ & E. Paudel and P. Mishra & Nepal \\
\hline Research Paper & $\begin{array}{l}\text { Effect of Detoxified Expeller Pressed and Dehulled } \\
\text { Jatropha (Jatropha curcas) Meals in Poultry Feed } \\
\text { Formulations }\end{array}$ & $\begin{array}{l}\text { M. Prasad, R. K. Devappa, } \\
\text { S.P. Muthukumar, B. } \\
\text { Swamylingappa }\end{array}$ & India \\
\hline Research Paper & $\begin{array}{l}\text { Effect of Pre Treatment on the Bacteriological and } \\
\text { Physical Qualities of Spices and Herbs used in Thai } \\
\text { Green Curry and Antibacterial Property of the Curry } \\
\text { Extract }\end{array}$ & $\begin{array}{l}\text { B. O. T. Ifesan, S. } \\
\text { Siripongvutikorn, P. } \\
\text { Thummaratwasik and D. } \\
\text { Kanthachote }\end{array}$ & Thailand \\
\hline Research Paper & $\begin{array}{l}\text { An Alternative Simplified Attribute Sampling Plan } \\
\text { for Food Product Control }\end{array}$ & R. P. Khatiwada & Nepal \\
\hline Research Paper & $\begin{array}{l}\text { Mathematical Modelling of Drying Kinetics of Apple } \\
\text { Pomace }\end{array}$ & $\begin{array}{l}\text { R. Shalini, D. K. Gupta and } \\
\text { A. Singh }\end{array}$ & India \\
\hline Research Note & Fast Food (Noodle) and Insulin Resistance in Mice & $\begin{array}{l}\text { S. Sitole, S. Gaherwal and } \\
\text { M. M. Prakash }\end{array}$ & India \\
\hline Research Note & Is Nepalese Honey Free from Pesticides? & $\begin{array}{l}\text { P. Koirala, N. R. Dahal, } \\
\text { M.R. Bhandari, G. Dawadi, } \\
\text { J. P. Lama, and U.K. } \\
\text { Bhattarai }\end{array}$ & Nepal \\
\hline Research Note & $\begin{array}{l}\text { Microbial Quality Evaluation of Probiotic Yoghurt witl } \\
\text { Market Yoghurt Collected from Kathmandu Valley }\end{array}$ & C.M. Bhandari & Nepal \\
\hline Research Note & $\begin{array}{l}\text { Bacteriological Analysis of Drinking Water of } \\
\text { Kathmandu Metropolitan City }\end{array}$ & $\begin{array}{l}\text { I. B. Pachhai, O. P. Panta, } \\
\text { V. S. Chhetri and P. Poudel }\end{array}$ & Nepal \\
\hline Research Note & $\begin{array}{l}\text { Selection of Appropriate Wine Yeast Strain for Plum } \\
\text { Wine Fermentation }\end{array}$ & $\begin{array}{l}\text { E. Shrestha, S. Rana, K. } \\
\text { Dahal and T.B. Karki }\end{array}$ & Nepal \\
\hline Research Note & $\begin{array}{l}\text { Clostridium Perfringens in Meat Products Collected } \\
\text { From Kathmandu Valley }\end{array}$ & $\begin{array}{l}\text { V. S. Chhetri, T. B. Karki } \\
\text { and I. B. Pachhai }\end{array}$ & Nepal \\
\hline Research Note & $\begin{array}{l}\text { Preparation of Sinki as an Intermediate Moisture Food : } \\
\text { Quality Evaluation }\end{array}$ & P. Ojha and S.B. Katawal & Nepal \\
\hline Research Note & Microbial Quality of Jar Water Sold in Kathmandu & P. Bhandari, S. Khanal, M. & Nepal \\
\hline
\end{tabular}


Dahal \& Dawadi : J. Food Sci. \& Technol. Nepal, 6 (122-129), 2010

Valley

Viewpoint

Short communication
Mittle, M. Gupta, R.

Maharjan, R. Shakya and

D.R. Joshi

Relation between Health and Food: View Point of Com U. Shrestha

Mushroom Poisoning Problem in Nepal

U. Ray

Nepal

Nepal

(Source: NEFOSTA, 2009)

Table 8. Reviewer's list for JFSTN, Vol 1, 2005 to Vol 5, 2009

\begin{tabular}{lll}
\hline \multicolumn{1}{c}{ Name } & \multicolumn{1}{c}{ Address } & Country \\
\hline Amin Ismail & Department of Nutrition and Dietetics, University Putra Malaysia, Serdang & Malaysia \\
Ashok Shrestha & Center for Nutrition and Food Science, The University of Queensland, Briswane & Australia \\
Barbatunde A. & Department of Agriculture Engineering, Federal University of Technology, & Nigeria \\
Adewumi & Akure, & Australia \\
Benu Prasad Adhikary & School of Engineering, The University of Queensland, Briswane, & India \\
Bhagya Swamy & Central Food Technological Research Institute (CFTRI), Mysore, & Australia \\
Lingappa & & Nepal \\
Bhesh Raj Bhandari & Center for Nutrition and Food Science, The University of Queensland, Briswane & \\
Bhupal Govinda & Kathmandu University, Dhulikhel, Kavre & Canada \\
Shreshta & & Nepal \\
Desh Subba & Ruminant Scientist, Avenue Apartment, NE Calgary, AB, T1Y 4P9, & Nepal \\
Dev Bhakta Shakya & Federation of Nepalese Chamber of Commerce and Industry (FNCCI), & Nepal \\
Kilip Subba & Rathmandu & India \\
Ganga Kharel, & Trivuwan University, Kirtipur, Kathmandu & India \\
Jamuna Prakash & Department of Studies in Food Science and Nutrition, University of Mysore & Japan \\
Kiran Bains & Punjab Agriculture University, Ludhiana, Punjab & Australia \\
Megh Raj Bhandari & Graduate School of Agriculture, Hokkaido University, Sapporo Shi. & Nepal \\
Nagendra Shah & University of Victoria & Nepal \\
Sanjay Bista & Nepal Agriculture Research Council, Lalitpur & Nepal \\
Suroj Pokhrel & Department of Agriculture, Government of Nepal & Canada \\
Tika Bahadur Karki & Kathmandu University, Dhulikhel, Kavre, Nepal & Srilanka \\
Tirtha Bajagain & Department of Bioresource Engineering, McDonald Campus of McGill University & \\
Upul Marapana & Department of Animal Science, Facaulty of Agriculture, University of Ruhuna & \\
\hline (Source: NEFOSTA, 2005 NoFOSTA, 2009) &
\end{tabular}

(Source: NEFOSTA, 2005 to NEFOSTA, 2009)

\section{References}

AFST (I) (2003). Journal of Food Science and Technology (India), Volume 40, Number 1, 2003

Agreement made between NEPJOL and NEFOSTA at June 8, 2009

NEFOSTA (2005). Journal of Food Science and Technology Nepal, Volume 1, 2005

NEFOSTA (2006). Journal of Food Science and Technology Nepal, Volume 2, 2006
NEFOSTA (2007). Journal of Food Science and Technology Nepal, Volume 3, 2007

NEFOSTA (2008). Journal of Food Science and Technology Nepal, Volume 4, 2008

NEFOSTA (2009). Journal of Food Science and Technology Nepal, Volume 5, 2009

Recognition Letter received by ISSN office France at July 20, 2005 